\title{
Laboratory and Field Trials to Identify Sustainable Chemical Control Strategies for Trioza erytreae in European Citrus Orchards
}

\author{
Miguel A. Dionisio ${ }^{1}$, Estrella Hernández-Suárez ${ }^{1}\left(\mathbb{D}\right.$, Felipe Siverio ${ }^{1,2}{ }^{(}$, Juan M. Arjona-López ${ }^{3, *} \mathbb{C}$, \\ Aurea Hervalejo $^{3}$ (i) and Francisco J. Arenas-Arenas ${ }^{3}$ (D)
}

1 Unidad de Protección Vegetal, Instituto Canario de Investigaciones Agrarias (ICIA), Apdo. 60, 38200 La Laguna, Spain; miguelangeldionisio@hotmail.com (M.A.D.); ehernand@icia.es (E.H.-S.); fsiverio@icia.es (F.S.)

2 Sección de Laboratorio de Sanidad Vegetal, Consejería de Agricultura, Ganadería y Pesca del Gobierno de Canarias, Ctra, El Boquerón, s/n, 38270 La Laguna, Spain

3 Department of Agri-Food Engineering and Technology, Andalusian Institute of Agricultural and Fisheries Research and Training (IFAPA), "Las Torres" Center, Ctra, Sevilla-Cazalla de la Sierra Km. 12.2, Alcalá del Río, 41200 Seville, Spain; aurea.hervalejo@juntadeandalucia.es (A.H.); fjose.arenas@juntadeandalucia.es (F.J.A.-A.)

* Correspondence: juanm.arjona@juntadeandalucia.es

check for updates

Citation: Dionisio, M.A.; Hernández-Suárez, E.; Siverio, F.; Arjona-López, J.M.; Hervalejo, A.; Arenas-Arenas, F.J. Laboratory and Field Trials to Identify Sustainable Chemical Control Strategies for Trioza erytreae in European Citrus Orchards. Agronomy 2021, 11, 1982. https:// doi.org/10.3390/agronomy11101982

Academic Editor: Olivia Reynolds

Received: 9 August 2021

Accepted: 29 September 2021

Published: 30 September 2021

Publisher's Note: MDPI stays neutral with regard to jurisdictional claims in published maps and institutional affiliations.

Copyright: (C) 2021 by the authors. Licensee MDPI, Basel, Switzerland. This article is an open access article distributed under the terms and conditions of the Creative Commons Attribution (CC BY) license (https:// creativecommons.org/licenses/by/ $4.0 /)$.

\begin{abstract}
Trioza erytreae (Del Guercio) is one of the psyllid insect vectors of the causal agents of huanglongbing. This paper proposes an assessment of the effectiveness of several pesticides with and without a pine oil-based organic adjuvant, in order to contain the spread and population of this pest and reduce the side effects on the Tamarixia dryi parasitoid. Five insecticides and their combinations with pine oil were sprayed against T. erytreae on citrus trees under semi-field and field conditions. The effect of the same treatments was assessed on T. dryi under laboratory conditions. All insecticides, except for acetamiprid, increased their effectiveness when combined with pine oil under both conditions. Cyantraniliprole, dimethoate, and their respective combinations with the organic adjuvant showed the highest efficacies against T. erytreae. Under laboratory conditions, dimethoate reported the most negative effect on $T$. dryi activity whereas cyantraniliprole and its combination with pine oil yielded a low toxicity effect on this parasitoid. Our results recommend the development of an integrated control approach for citrus growers based on an insecticide rotation program, preventing the emergence of pest resistance to one substance. In this sense, other insecticides, such as lambda-cyhalothrin with pine oil adjuvant or acetamiprid, could be considered.
\end{abstract}

Keywords: African citrus psyllid; citrus; insecticides; integrated pest management; side effects; Tamarixia dryi

\section{Introduction}

Spain is the sixth largest citrus-growing country worldwide and the first in the European Union and the Mediterranean Basin, with a total production of six million tons in 2019. The Mediterranean Basin, with an overall production of 26.7 million tons, is the second largest citrus-growing area worldwide behind China in 2019 [1].

Huanglongbing (HLB), or Citrus Greening, is one of the most devastating citrus diseases worldwide; it is caused by three species of uncultured, phloem-restricted, obligate parasite, and proteobacteria: Candidatus Liberibacter asiaticus (Jagoueix, Bové, and Garnier) (CLas), Candidatus Liberibacter africanus (Jagoueix, Bové and Garnier) (CLaf), and Candidatus Liberibacter americanus (Teixeira, Saillard, Eveillard, Danet, da Costa, Ayres \& Bové) (CLam) [2-6]. Trees infected with this pathogen become unproductive and die over time [2,7]. In Florida, this disease has generated major financial losses up to USD 3.63 billion and has reduced orange juice production since 2006 [8]. 
This pathogen has spread throughout the main citrus-growing regions of the world, except for Australia and the Mediterranean Basin $[9,10]$. Nevertheless, some regions of the Arabian Peninsula and equatorial and western Africa have been colonized by it in recent years, becoming a major concern for HLB-free citrus areas [11-14].

Candidatus Liberibacter spp. can be transmitted through grafting by two psyllids vectors, Diaphorina citri (Kuwayama) and Trioza erytreae, from infected citrus plants to healthy citrus plants and/or naturally (Del Guercio) [2,15]. The transmission of CLas and CLam has been associated with Asian citrus psyllid (D. citri, AsCP), while CLaf has been associated with African citrus psyllid (T. erytreae, AfCP) [2]. Further, T. erytreae has recently been described as carrying CLas in Ethiopia [16].

AfCP is considered native to southern Africa [17]. In Europe, this pest was first detected in Madeira island in 1994 [18]. While no bacterial species that causes HLB have been found in Spain yet [14], AfCP (T. erytreae) was first identified in the Canary Islands in 2002 [19]. Later, this insect appeared in Galicia, in 2014, and in northern mainland Portugal in 2015, and more recently in Asturias, Cantabria, and the Basque Country in 2020 [10,20]. Since it was detected, the insect has spread widely throughout the Canary archipelago, except for Fuerteventura and La Graciosa islands, and in the Iberian mainland, near major citrus-growing areas, such as the Algarve region in Portugal and the Huelva province in Spain [21-24]. This poses a great risk for the Mediterranean citrus sector and, consequently, the search for sustainable pest control methods to prevent it from spreading is a priority.

AfCP can cause direct damage on citrus crops; psyllid nymphs feed from phloem sap in young leaves, yielding typical symptoms of open gall-like structures on the leaves. Further, adults and nymphs produce a significant amount of honeydew while feeding, which fall on leaves and fruit, inducing the growth of fungi, such as Capnodium spp. [21-23]. Thus, in high population levels, this substantial damage can lead to shoot distortion, but no defoliation in developed leaves, inducing the reduction of photosynthetic capacity and fruit devaluation. Moreover, honeydew attracts ants as food that protect the pest from natural enemies, disrupting biological control [23].

Vector control is deemed to be the basic strategy for HLB management [25]. Chemical control through broad-spectrum pesticides, such us systemic chloronicotinyl insecticides, has been the most common measure to manage AfCP in African regions where the pest is well-spread $[17,23]$. In Europe, the neonicotinoid thiamethoxam was the most common and effective active ingredient used to fight this pest in infested areas until April 2019 [26]; however, this compound is banned from use in agriculture of European Union countries by the Regulation (EU) 2018/785 of 29 May, 2018. The remaining neonicotinoid compounds are banned from use, except for acetamiprid and imidacloprid, with the latter not being allowed in open-air conditions [27]. This poses a primary challenge for the Mediterranean citrus sector, since the lack of alternatives and overuse of active ingredients, especially if treatment rotation is not considered [28], leads to increasing pest resistance over time [28-32]. Furthermore, the control of other psyllid species, such as Diaphorina citri or Bactericera cockerelli (Sulc), with the use of other active ingredients, including acetamiprid, lambda-cyhalothrin and cyantraniliprole [33-35], as potential candidates against AfCP has yielded successful results. Nevertheless, an exclusively chemical-based strategy seems insufficient due to the presence of scattered orchards and gardens, representing reservoirs and spreading points [4,23]. Moreover, new environmental trends [36], consumer concerns surrounding food safety [37,38], and European restrictions on the use of synthetic agrochemicals (Directive 2009/128/CE) [27] are aimed at reducing the use of pesticides. In this context, an integrated pest management strategy, combining the use of preventive, cultural, chemical, and biological control methods, is highly recommended.

Among the natural enemies of AfCP, the parasitic wasp Tamarixia dryi (Waterston) is effective in controlling the T. erytreae population in its area of origin [39-42]. This wasp is an ectoparasitoid, which oviposits its eggs on the third to fifth nymphal stages of T. erytreae, and its nymphs feed on them throughout its development [24,43]. Classical biological control with this wasp has effectively reduced the populations of T. erytreae on the islands 
of Mauritius, Reunion Islands, and St. Helena [41,44,45]. Such previous and positive results, combined with the lack of effective biological control agents against $T$. erytreae native to the Iberian Peninsula and Atlantic islands, led to the use of a classic biological control strategy in Spain [23,46]. Urbaneja-Bernat et al. [24] carried out a host range test of T. dryi that confirmed that this natural enemy is a highly specific parasitoid, and its introduction in Europe should not affect other psyllid species. Thus, individuals of this ectoparasitoid were collected from several citrus orchards from Pretoria (South Africa) and introduced in the Canary Islands (Spain) to control the population of the psyllid vector (AfCP), showing positive results and spread capabilities [43,47]. In 2020, this positive work contributed to the first experimental releases on the northern Iberian mainland, including Galicia (Spain) and Portugal in lemon trees orchards [48]. However, the success of this parasitoid in European citrus orchards in the future will be contingent on the availability of selective insecticides for AfCP pest management. Moreover, little research is available into the lethal effect of insecticides on T. dryi, as with other species of Tamarixia such as T. radiata (Waterston) $[49,50]$.

In order to develop integrated control strategies against AfCP, the aims of this study were: (i) to assess the efficacy of several insecticides with and without an organic adjuvant for T. erytreae chemical control; and (ii) to assess the lethal effects at different stages of the parasitic wasp T. dryi in order to select the best combination for integrated control.

\section{Materials and Methods}

\subsection{Insecticides and Adjuvant}

The five insecticides used in these assays are listed in Table 1. Twelve treatments were carried out in all trials: five insecticides were sprayed separately and with an adjuvant, as well as water with and without adjuvant as control treatments. The adjuvant used (Table 1) is a commercial product comprised of pine oil, which increases the contact action and coverage of foliar applied pesticides to improve the contact action and the coverage of these applications in all types of crops.

All insecticides were applied at the commercially recommended dose and were selected as they were authorized to control other citrus sucking pests or they were effective in psyllid control in other crops. They have either, contact action, systemic action or both In all cases, a $\mathrm{pH}$ regulator (Triple color ${ }^{\circledR}$ ) was used in each treatment preparation, and a protective plastic screen was placed between adjacent plants (semi-field) or trees (field) during insecticide application in order to avoid spray drift.

Table 1. Insecticides and adjuvant screened in this study.

\begin{tabular}{|c|c|c|c|c|c|}
\hline Active Ingredient & Trade Name & PSA/MoA & Chemical Subgroup & $\begin{array}{l}\text { Concentration/ } \\
\text { Formulation }\end{array}$ & Manufacturer \\
\hline dimethoate & Perfekthion Top ${ }^{\circledR}$ & AChE I inhibitor & 1B Organophosphate & $40 \% \mathrm{EC}$ & BASF \\
\hline $\begin{array}{l}\text { L. cyhalothrin } \\
\text { acetamiprid }\end{array}$ & $\begin{array}{c}\text { Kenotrin }^{\circledR} \\
\text { Epik }^{\circledR}\end{array}$ & $\begin{array}{l}\text { VGSC I modulator } \\
\text { nAChR I antagonist }\end{array}$ & $\begin{array}{c}\text { 3A Pyrethroid } \\
\text { 4A Neonicotinoid }\end{array}$ & $\begin{array}{l}2.5 \% W G \\
20 \% \mathrm{SG}\end{array}$ & $\begin{array}{c}\text { Kenogard } \\
\text { Sipcam Iberia }\end{array}$ \\
\hline flonicamid & Teppeki $^{\circledR}$ & $\mathrm{CO} \mid$ modulator & 9C Pyridine & $50 \% \mathrm{WG}$ & $\begin{array}{l}\text { Belchim Crop } \\
\text { Protection }\end{array}$ \\
\hline $\begin{array}{c}\text { cyantraniliprole } \\
\text { Pine oil }\end{array}$ & $\begin{array}{c}\text { Minecto Alpha }{ }^{\circledR} \\
\text { Retenol }^{\circledR}\end{array}$ & $\operatorname{Rr} \mid$ modulators & 28 Diamides & $\begin{array}{l}10 \% \mathrm{SE} \\
\mathrm{EC}\end{array}$ & $\begin{array}{l}\text { Syngenta } \\
\text { Daymsa }\end{array}$ \\
\hline
\end{tabular}

PSA: Primary site of action; MoA: Insecticide Resistant Action Committee Mode of Action group; Abbreviations: AChE: acetylcholinesterase; VGSC: voltage gated sodium channel; nAChR: nicotinic acetylcholine receptor; CO: chordotonal organs; Rr: ryanodine receptor [51,52]. L. cyhalothrin: lambda-cyhalothrin; EC: Emulsifiable concentrate; WG: Water dispersible granulates; SG: water-soluble granulates; SE: suspo-emulsion. 


\subsection{Insecticide Effect on T. erytreae in Semi-Field Conditions}

\subsubsection{Trial Location}

This trial was set up during June 2019 in an experimental greenhouse belonging to the Instituto Canario de Investigaciones Agrarias (ICIA) in Gran Canaria island (Municipality of Pozo Izquierdo: $27^{\circ} 50^{\prime} 35.83^{\prime \prime}$ N, $15^{\circ} 25^{\prime} 48.88^{\prime \prime}$ W) Canary Islands, Spain. Citrus sinensis ('Washington Navel' cultivar) potted plants around 100-120 cm in height were used. Plants were maintained by drip irrigation throughout the trial. Temperature and relative humidity values were continuously recorded during the trial period using an OM-92 OMEGA data logger with protective housing. The average, maximum and minimum temperatures recorded were $26.6,34.1$ and $21.3{ }^{\circ} \mathrm{C}$, respectively. The average, maximum and minimum relative humidities recorded were $56.5 \%, 72.6 \%$, and $39.7 \%$, respectively.

\subsubsection{Insect Source and Inoculation}

All insects used in the semi-field trial for plant inoculation were collected in two insecticide-free lemons (Citrus limon (L.) Osbeck) orchards located in the northern part of the island of Gran Canaria (Canary Islands, Spain)) in the Municipality of Valleseco $\left(28^{\circ} 3^{\prime} 45.42^{\prime \prime} \mathrm{N}, 15^{\circ} 34^{\prime} 26.45^{\prime \prime} \mathrm{W}\right)$ at 800 m.a.s.l. (meters above the sea level) All insects were collected within $48 \mathrm{~h}$ of infestation of experimental plants. Adult insects were captured in $13 \mathrm{~mL}$ test tubes by entomological vacuum and stored in a cooler box for transportation and plant inoculation in the greenhouse.

Thirty-six potted citrus plants were artificially infested with T. erytreae adults. Citrus plants were previously pruned to ensure homogeneity in flushing. Up to two $2-4 \mathrm{~cm}$ long shoots per plant were inoculated and pocketed with tulle bags. Adults were kept in shoots for a maximum of four days; thus, encouraging the laying of eggs. After the inoculation period, only those plants with a presence of 100-200 T. erytreae individuals (eggs and $\mathrm{N}_{1}-\mathrm{N}_{2}$ nymphs) per shoot in at least two shoots were selected. These shoots were marked and were correctly numbered for suitable mortality monitoring after treatments. Tulle bags were removed before treatments and repositioned once finished; thus, preventing entry of T. dryi parasitoids or other natural enemies.

\subsubsection{Experimental Design, Treatments, and Psyllid Assessment}

Thirty-six plants were selected for the treatments (each plant with two marked shoots with 100-200 T. erytreae individuals were considered as an experimental unit). Thus, one plant per treatment was set up in a randomized complete block design comprising 12 treatments that were replicated three times. For each treatment, one liter of insecticide solution was prepared (Table 2) and applied using a manual sprayer (Matabi EKO $1000 \mathrm{~mL}$; Goizper Group, Antzuola, Gipuzkoa, Spain). The entire surface of the plant was sprayed with fine droplets, preventing excessive treatment and dripping.

Number of T. erytreae eggs, nymphs, and adults in each shoot were counted before the treatment and 5, 7, 14, 21, and 28 days after treatment application (daa). Counting was performed using a head magnifying glass (8PK-MA003N 1.8 $\times, 2.3 \times, 4.8 \times$; Proskit Industries Co., Ltd., New Taipei City, Taiwan) that facilitated shoot handling with both hands.

\subsection{Insecticide Effect on T. erytreae in Field Conditions}

\subsubsection{Trial Location}

A field experiment was carried out during July 2019 in a commercial lemon orchard (Citrus limon (L.) Osbeck) located in the northern part of Gran Canaria in the Municipality of Valleseco $\left(28^{\circ} 3^{\prime} 45.42^{\prime \prime} \mathrm{N}, 15^{\circ} 34^{\prime} 26.45^{\prime \prime} \mathrm{W}\right)$ at 800 m.a.s.l. For orchard selection, several criteria were applied: (1) no chemical treatments had been applied in recent years; (2) homogeneous pest presence; (3) homogeneous new shoots presence.

Weather conditions during insecticide application were recorded using a PCE-THA 10 thermohygrometer. Temperature and humidity were taken using an OM-92 OMEGA data logger with a protective housing throughout the study. During the trial period, the average, maximum and minimum temperatures were $15.8,24.3$, and $10.4{ }^{\circ} \mathrm{C}$, respectively, 
and the average, maximum, and minimum relative humidities were $74.7 \%, 93.7 \%$, and $50.7 \%$, respectively.

Table 2. Treatments applied in semi-field and field studies.

\begin{tabular}{|c|c|}
\hline Treatment & Dose \\
\hline Control & \\
\hline Pine oil & $100 \mathrm{cc}$ of a.i./hl \\
\hline dimethoate & $150 \mathrm{cc}$ of a.i./hl \\
\hline dimethoate + pine oil & $150 \mathrm{cc}$ of a.i. $/ \mathrm{hl}+100 \mathrm{cc}$ of a.i. $/ \mathrm{hl}$ \\
\hline L. cyhalothrin & $80 \mathrm{~g}$ of a.i. $/ \mathrm{hl}$ \\
\hline L. cyhalothrin + pine oil & $80 \mathrm{~g}$ of a.i. $/ \mathrm{hl}+100 \mathrm{cc}$ of a.i. $/ \mathrm{hl}$ \\
\hline acetamiprid & $50 \mathrm{~g}$ of a.i. $/ \mathrm{hl}$ \\
\hline acetamiprid + pine oil & $50 \mathrm{~g}$ of a.i $/ \mathrm{hl}+100 \mathrm{cc}$ of a.i. $/ \mathrm{hl}$ \\
\hline flonicamid & $5 \mathrm{~g}$ of a.i. $/ \mathrm{hl}$ \\
\hline flonicamid + pine oil & $5 \mathrm{~g}$ of a.i. $/ \mathrm{hl}+100 \mathrm{cc}$ of a.i. $/ \mathrm{hl}$ \\
\hline cyantraniliprole & $125 \mathrm{cc}$ of a.i. $/ \mathrm{hl}$ \\
\hline cyantraniliprole + pine oil & $125 \mathrm{cc}$ of a.i. $/ \mathrm{hl}+100 \mathrm{cc}$ of a.i. $/ \mathrm{hl}$ \\
\hline
\end{tabular}

L. cyhalothrin: lambda-cyhalothrin; a.i.: active ingredient.

\subsubsection{Experimental Design, Treatments, and Psyllid Assessment}

Seventy-two trees were selected on account of their similar size and canopy volume, health status, and pest level. The experiment was arranged as a randomized complete block design with three replicates of twelve treatments; the experimental plot consisted of two nearby trees, avoiding perimeter trees at every replicate.

In each tree, three shoots that were naturally infested by AfCP with the presence of eggs and $\mathrm{N}_{1}-\mathrm{N}_{2}$ nymphs of $T$. erytreae $(\approx 100-200$ individuals per shoot) were selected. Only 3-4 leaves per shoot were chosen, removing the remaining leaves. All selected shoots were covered by tulle bags in order to catch and count emerged adults, avoiding new egg laying, and preventing T. dryi parasitoid interferences.

Before spraying, tulle bags were removed and replaced after the treatment. A batterysprayer KURIL KSP 18D (12 V, 7 Ah, 18 L, 4 bar pressure and membrane pump; Pereiro de Aguiar, Ourense, Spain) with a $1.6 \mathrm{~mm}$ spray nozzle was used for each insecticide application. The 12 treatment compounds (Table 2) were used for this trial. An average preparation volume of 5.54 litres per treatment was used per tree application and a piece of $26 \times 76 \mathrm{~mm}^{2}$ hydro-sensitive paper (Syngenta Crop Protection AG, Basel, Switzerland) was placed next to each selected shoot in order to ensure the homogeneity of every treatment.

The number of T. erytreae eggs, nymphs, and adults was counted before and 7, 14, 21, and 28 days after application in each shoot selected. This assessment process was carried out using the head magnifying glass described for semi-field trial.

\subsection{Acute Toxicity of Insecticides to T. dryi}

Two different bioassays were carried out in May and June 2019, one with T. dryi pupae (most tolerant stage), and another with T. dryi adults (the most susceptible stage to insecticides). Both bioassays were set-up in the laboratory at the ICIA facilities in Pozo Izquierdo (Gran Canaria) at room temperature. Temperature and humidity were recorded using an OM-92 OMEGA data logger throughout the study. During the trial period, the average, maximum, and minimum temperatures were $26.7,27.5$, and $25.8^{\circ} \mathrm{C}$, respectively, and the average, maximum, and minimum relative humidities were $55.3 \%, 60.1 \%$, and $50.6 \%$, respectively.

\subsubsection{Effect on T. dryi Pupae}

To obtain parasitoid pupae, leaves with parasitized T. erytreae nymphs were collected from a non-treated area in the same commercial lemon orchard as described above for the field trial, stored in plastic bags, kept in a cooler box for transportation, and stored in a refrigerator at $10^{\circ} \mathrm{C}$ in the laboratory until use required. 
Each experimental unit consisted of one citrus leaf with a total of ten parasitized T. erytreae $\mathrm{N}_{4}-\mathrm{N}_{5}$ nymphs (with clearly visible external meconium) placed in individual glass tubes with the leaf petiole immersed in water free $(2 \mathrm{~mL})$ as humidity sources. Parasitized nymphs were selected using a stereo microscope (40×; MoticEurope, S.L.U., Barcelona, Spain) and marked alongside the leaf with a permanent marker dot, with the remaining nymphs being discarded using a dissecting needle.

The same insecticide treatments described in Table 2 were used for this experiment at a volume solution of $100 \mathrm{~mL}$. Leaves were treated by immersion in $100 \mathrm{~mL}$ plastic pots, placed on laboratory filter paper for one-hour air-drying, and lastly arranged in a completely randomized design with six replicates of twelve treatments. The number of nymphs with and without emerging holes were counted after a seven-day incubation period.

\subsubsection{Effect on T. dryi Adults}

A total of 1440 T. dryi adults up to $72 \mathrm{~h}$ old were required every week. Plant material with parasitized T. erytreae nymphs was regularly collected from non-treated trees in the same commercial lemon orchard described above and placed in a ventilated insect emergence cage for adult wasp. Adult wasps ( $\leq 72 \mathrm{~h}^{\prime}$ life) were extracted using an entomological aspirator, grouped into clusters of ten within ventilated $13 \mathrm{~mL}$ test tubes, and kept refrigerated at $10^{\circ} \mathrm{C}$ for bioassay set up.

Acute toxicity of the selected insecticides (Table 2) against T. dryi adults was assessed both in fresh residue ( $3 \mathrm{~h}$ after the application (haa)) and in dry residue (7, 14, and $21 \mathrm{daa}$ ) using leaf discs $(2.5 \mathrm{~cm} \varnothing)$ of $C$. sinensis ('Washington Navel' cultivar) punched from sprayed plants (in similar way and conditions as for the semi-field trial). The experimental unit consisted of a ventilated petri dish $(4.5 \mathrm{~cm} \mathrm{Ø)} \mathrm{containing} \mathrm{a} \mathrm{treated} \mathrm{leaf} \mathrm{disc} \mathrm{on} 2 \%$ agar (to prevent leaf-disc for drying) with ten T. dryi adults (five males and five females) up to $72 \mathrm{~h}$ old and supplemented with a couple of organic honey droplets as food (Figure 1). The experiment consisted of four replicates per treatment (40 T. dryi adults per treatment) that were fully randomized and repeated twice. Mortality was assessed $24 \mathrm{~h}$ after exposure using the same stereo microscope as previously described.

A

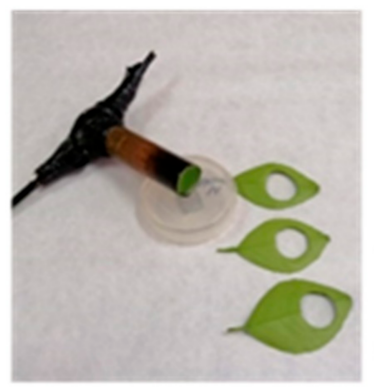

B

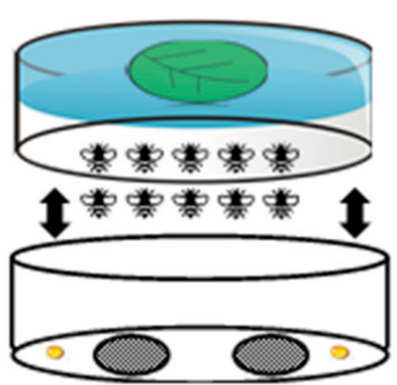

$\mathrm{C}$

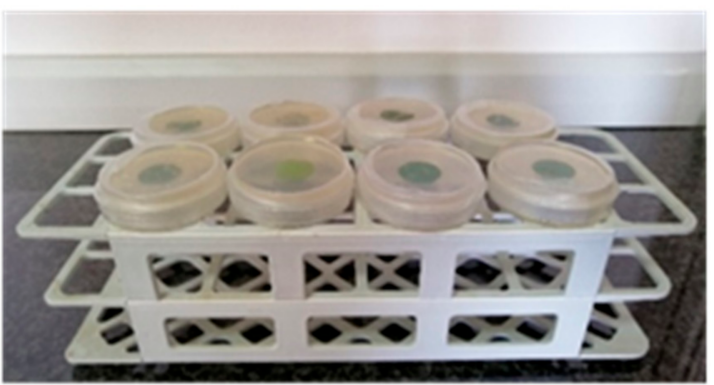

Figure 1. (A) Leaf discs cut through a cork borer. (B) Overview of assembly of each. Petri dish. (C) Inverted Petri dishes in a laboratory rack.

\subsection{Data Analysis}

For each experiment, raw values obtained were used to calculate the percentage of corrected mortality (PM; \%) considering the total individuals counted (eggs + nymphs + adults). PM was adjusted to the control treatment using Abbott's equation [53] as $\mathrm{PM}=100(\mathrm{C}-\mathrm{T}) / \mathrm{C}$ (where $\mathrm{C}=$ average of alive individuals from the control treatment for each assessment timing; $\mathrm{T}=$ alive individuals per each sample replicate, treatment, and assessment timing) and this parameter was calculated for each elemental unit of the experiments. Raw PM values were analyzed through a one-way ANOVA and Fisher's LSD test $(p<0.05)$ [54] using the free software R version 4.0.2 [55] with the package "agricolae" [56]. For parasitoid results, pesticides were classified into four toxicity categories 
according to guidelines for beneficial organisms of IOBC/WPRS (pesticides and beneficial organisms): Class $1=\mathrm{PM}<25 \%$ (harmless); Class $2=25 \leq \mathrm{PM} \leq 50 \%$ (slightly harmful); Class $3=51 \leq \mathrm{PM} \leq 75 \%$ (moderately harmful); and Class $4=\mathrm{PM}>75 \%$ (harmful) [57-59].

\section{Results}

\subsection{Evaluation of the Combination of Five Insecticides with an Organic Adjuvant on T. erytreae} under Semi-Field Conditions

At 5 daa, the PM of T. erytreae individuals (eggs and nymphs) did not show statistical differences among the treatments assayed $\left(\mathrm{F}_{10 ; 54}=1.32\right.$; and $\left.p=0.24\right)$. The highest value of PM was achieved with a cyantraniliprole + adjuvant (pine oil) treatment with a percentage higher than $70 \%$, followed by lambda-cyhalothrin + pine oil, acetamiprid, cyantraniliprole, dimethoate + pine oil, acetamiprid + pine oil, flonicamid + pine oil, dimethoate, lambdacyhalothrin, flonicamid, and pine oil without significant differences. At 7 daa, the PM of T. erytreae individuals did not yet display significant differences among the treatments assayed $\left(\mathrm{F}_{10 ; 54}=1.69\right.$; and $\left.p=0.11\right)$. The highest mortality response against $T$. erytreae individuals was reached with the treatment lambda-cyhalothrin + pine oil $(74.06 \%)$, followed by cyantraniliprole + pine oil, acetamiprid, dimethoate + pine oil, cyantraniliprole, acetamiprid + pine oil, dimethoate, flonicamid + pine oil; lambda-cyhalothrin, flonicamid, and pine oil. The PM of T. erytreae individuals showed with significant differences among the treatments assayed at 14 daa $\left(\mathrm{F}_{10 ; 54}=3.14\right.$; and $\left.p=0.003\right)$. The combined treatment of cyantraniliprole + pine oil showed the highest mortality on insect individuals, followed by acetamiprid, lambda-cyhalothrin + pine oil, dimethoate + pine oil, and cyantraniliprole without significant differences. Thus, the remaining of the treatments assayed showed the lowest significant mortality rates. At 21 daa, the PM of T. erytreae individuals were statistically different among the treatments assayed $\left(\mathrm{F}_{10 ; 54}=5.72\right.$; and $\left.p<0.001\right)$. The combination of cyantraniliprole + pine oil again reported the highest mortality effect, followed by acetamiprid, cyantraniliprole, lambda-cyhalothrin + pine oil, dimethoate + pine oil, and without significant differences. The PM of the other treatments showed lower significant mortality compared with cyantraniliprole + pine oil, with pine oil alone displaying the lowest mortality. Lastly, at 28 daa, all PM values of T. erytreae individuals showed significant differences $\left(\mathrm{F}_{10 ; 54}=8.07\right.$; and $\left.p<0.001\right)$ among the treatments assayed. Thus, cyantraniliprole combined with pine oil again achieved the highest PM in all the experiments, followed by cyantraniliprole, acetamiprid, dimethoate + pine oil, lambda-cyhalothrin + pine oil, and dimethoate without significant differences. The remaining treatments showed lower significant mortality rates, and pine oil treatment alone recorded the lowest PM value. Overall, the mortality of all active ingredients tested against $T$. erytreae was improved with the organic adjuvant (pine oil), except in insecticide acetamiprid, in which this combination weakened its PM values in all assessment periods (Table 3).

Table 3. Effect of insecticides and their combinations with a pine oil based organic adjuvant on T. erytreae under semi-field conditions.

\begin{tabular}{|c|c|c|c|c|c|}
\hline \multirow{2}{*}{ Treatment } & \multicolumn{5}{|c|}{$\mathrm{PM}(\%) \pm \mathrm{SE}$} \\
\hline & 5 daa & 7 daa & 14 daa & 21 daa & 28 daa \\
\hline Pine oil & $17.86 \pm 8.62 \mathrm{~ns}$ & $23.87 \pm 11.48 \mathrm{~ns}$ & $27.47 \pm 12.52 \mathrm{~d}$ & $23.61 \pm 10.56 \mathrm{e}$ & $25.65 \pm 11.61 \mathrm{e}$ \\
\hline dimethoate & $44.13 \pm 11.01 \mathrm{~ns}$ & $50.89 \pm 16.13 \mathrm{~ns}$ & $56.11 \pm 13.31 \mathrm{bc}$ & $75.21 \pm 9.21 \mathrm{abc}$ & $77.46 \pm 10.04 \mathrm{abc}$ \\
\hline dimethoate + pine oil & $52.30 \pm 15.58 \mathrm{~ns}$ & $68.44 \pm 10.58 \mathrm{~ns}$ & $73.61 \pm 8.61 \mathrm{abc}$ & $79.17 \pm 0.09 \mathrm{abc}$ & $88.87 \pm 3.61 \mathrm{ab}$ \\
\hline L. cyhalothrin & $43.28 \pm 13.65 \mathrm{~ns}$ & $47.98 \pm 13.56 \mathrm{~ns}$ & $54.78 \pm 9.78 \mathrm{bc}$ & $61.81 \pm 9.94 \mathrm{~cd}$ & $65.04 \pm 5.67 \mathrm{~cd}$ \\
\hline L. cyhalothrin + pine oil & $66.20 \pm 7.33 \mathrm{~ns}$ & $74.50 \pm 5.31 \mathrm{~ns}$ & $77.01 \pm 4.07 \mathrm{ab}$ & $80.73 \pm 5.34 \mathrm{abc}$ & $79.13 \pm 4.89 \mathrm{abc}$ \\
\hline acetamiprid & $63.05 \pm 13.17 \mathrm{~ns}$ & $72.77 \pm 13.46 \mathrm{~ns}$ & $78.55 \pm 8.19 \mathrm{ab}$ & $87.33 \pm 4.75 \mathrm{ab}$ & $91.30 \pm 2.96 \mathrm{a}$ \\
\hline acetamiprid + pine oil & $48.85 \pm 11.44 \mathrm{~ns}$ & $59.37 \pm 8.55 \mathrm{~ns}$ & $60.65 \pm 7.56 \mathrm{bc}$ & $69.79 \pm 5.59 \mathrm{bcd}$ & $70.09 \pm 5.74 \mathrm{bcd}$ \\
\hline flonicamid & $42.05 \pm 14.34 \mathrm{~ns}$ & $43.04 \pm 14.81 \mathrm{~ns}$ & $49.54 \pm 12.89 \mathrm{~cd}$ & $49.48 \pm 11.87 \mathrm{~d}$ & $53.94 \pm 13.16 \mathrm{~d}$ \\
\hline flonicamid + pine oil & $46.98 \pm 12.34 \mathrm{~ns}$ & $49.71 \pm 10.23 \mathrm{~ns}$ & $55.25 \pm 8.55 \mathrm{bc}$ & $68.06 \pm 8.80 \mathrm{bcd}$ & $66.43 \pm 8.79 \mathrm{~cd}$ \\
\hline cyantraniliprole & $59.10 \pm 14.64 \mathrm{~ns}$ & $67.63 \pm 14.10 \mathrm{~ns}$ & $71.76 \pm 11.76 \mathrm{abc}$ & $81.42 \pm 11.06 \mathrm{abc}$ & $92.00 \pm 3.91 \mathrm{a}$ \\
\hline cyantraniliprole + pine oil & $70.20 \pm 14.48 \mathrm{~ns}$ & $74.06 \pm 14.92 \mathrm{~ns}$ & $88.73 \pm 6.41 \mathrm{a}$ & $97.05 \pm 2.09 \mathrm{a}$ & $98.09 \pm 1.91 \mathrm{a}$ \\
\hline
\end{tabular}

Values with different letters are significantly different among the treatments tested for each assessment period (Fisher's LSD test, $p<0.05)$.

PM: percentage of corrected mortality; SE: standard error; ns: not significant; daa: days after application; L. cyhalothrin: lambda-cyhalothrin.

Individuals expressed as the mean of PM $(\%) \pm$ standard error (SE) in different assessment timings (5; 7; 14; 21 and 28 daa). 


\subsection{Evaluation of the Combination of Five Insecticides with an Organic Adjuvant on T. erytreae under Field Conditions}

At 7 daa, the PM of T. erytreae individuals (eggs, nymphs and adults) reported statistical differences among the treatments assayed $\left(\mathrm{F}_{10 ; 187}=2.50\right.$; and $\left.p=0.008\right)$. The highest PM value was found in the cyantraniliprole + pine oil treatment, followed by dimethoate + pine oil, dimethoate, and acetamiprid treatments, without statistical differences. The remaining treatments reported significant lower mortality rates compared with cyantraniliprole + pine oil, and pine oil alone showed the lowest value. The PM of T. erytreae individuals was significantly different at 14 daa $\left(\mathrm{F}_{10 ; 187}=7.73\right.$; and $\left.p<0.001\right)$. Thus, the highest mortality value was again obtained with cyantraniliprole + pine oil treatment, followed by dimethoate + pine oil, dimethoate, acetamiprid, and acetamiprid + pine oil without statistical differences. The remaining treatments reported lower significant mortality, with the pine oil treatment reporting the lowest response. At 21 daa, the values of PM of T. erytreae individuals reported significant differences among the treatments assayed $\left(\mathrm{F}_{10 ; 186}=16.14 ;\right.$ and $\left.p<0.001\right)$. The highest PM was again achieved by the cyantraniliprole + pine oil treatment, followed by dimethoate + pine oil, dimethoate, cyantraniliprole, and acetamiprid, without significant differences. The remaining treatments showed lower significant mortality rates, with the lowest response being reported by the pine oil treatment alone. Lastly, at 28 daa, PM of T. erytreae individuals showed statistical differences among the treatments assayed $\left(\mathrm{F}_{10 ; 187}=23.12\right.$; and $\left.p<0.001\right)$. The combination of cyantraniliprole + pine oil achieved the highest mortality effect against $T$. erytreae, followed by dimethoate + pine oil, cyantraniliprole, dimethoate, lambda-cyhalothrin + pine oil, and acetamiprid, without statistical differences. The remaining treatments showed lower significant mortality values, with pine oil reporting the lowest mortality response. In general, all active ingredients tested in this field experiment against T. erytreae increased their PM response when combined with the organic adjuvant (pine oil), except for insecticide acetamiprid (Table 4).

Table 4. Effect of insecticides and their combination with a pine oil based organic adjuvant on T. erytreae under field conditions.

\begin{tabular}{|c|c|c|c|c|}
\hline \multirow{2}{*}{ Treatment } & \multicolumn{4}{|c|}{$\mathrm{PM}(\%) \pm \mathrm{SE}$} \\
\hline & 7 daa & 14 daa & 21 daa & 28 daa \\
\hline Pine oil & $16.00 \pm 0.34 \mathrm{e}$ & $18.15 \pm 6.62 \mathrm{~g}$ & $24.25 \pm 7.50 \mathrm{e}$ & $27.56 \pm 7.64 \mathrm{~d}$ \\
\hline dimethoate & $38.39 \pm 3.82 \mathrm{abc}$ & $59.83 \pm 6.37 \mathrm{abc}$ & $82.58 \pm 3.13 \mathrm{abc}$ & $87.48 \pm 1.92 \mathrm{ab}$ \\
\hline dimethoate + pine oil & $42.73 \pm 6.43 \mathrm{ab}$ & $65.70 \pm 5.83 \mathrm{ab}$ & $86.16 \pm 2.98 \mathrm{ab}$ & $91.85 \pm 2.08 \mathrm{a}$ \\
\hline L. cyhalothrin & $28.76 \pm 7.22$ bcde & $40.43 \pm 4.67 \mathrm{def}$ & $56.42 \pm 8.01 \mathrm{~d}$ & $59.02 \pm 7.79 c$ \\
\hline L. cyhalothrin + pine oil & $19.88 \pm 5.34 \mathrm{de}$ & $44.38 \pm 3.10$ cde & $67.53 \pm 5.28 \mathrm{~cd}$ & $82.53 \pm 2.96 \mathrm{ab}$ \\
\hline acetamiprid & $34.58 \pm 5.56 \mathrm{abcd}$ & $58.12 \pm 6.64 \mathrm{abcd}$ & $74.81 \pm 5.13 \mathrm{abc}$ & $80.42 \pm 3.88 \mathrm{ab}$ \\
\hline acetamiprid + pine oil & $27.09 \pm 6.05$ bcde & $56.40 \pm 5.31 \mathrm{abcd}$ & $72.08 \pm 5.87 \mathrm{bcd}$ & $76.10 \pm 6.09 b$ \\
\hline flonicamid & $24.86 \pm 8.34$ cde & $24.58 \pm 7.86 \mathrm{fg}$ & $33.41 \pm 8.19 \mathrm{e}$ & $29.45 \pm 7.55 \mathrm{~d}$ \\
\hline flonicamid + pine oil & $27.70 \pm 5.07$ bcde & $27.25 \pm 5.63 \mathrm{efg}$ & $30.61 \pm 6.97 \mathrm{e}$ & $38.06 \pm 7.86 \mathrm{~d}$ \\
\hline cyantraniliprole & $28.34 \pm 3.16$ bcde & $51.82 \pm 5.37 \mathrm{bcd}$ & $76.63 \pm 4.71 \mathrm{abc}$ & $90.10 \pm 2.11 \mathrm{ab}$ \\
\hline cyantraniliprole + pine oil & $46.57 \pm 6.82 \mathrm{a}$ & $71.43 \pm 4.69 \mathrm{a}$ & $88.95 \pm 2.64 \mathrm{a}$ & $93.74 \pm 1.92 \mathrm{a}$ \\
\hline
\end{tabular}

Values with different letters are significantly different among the treatments tested for each assessment period (Fisher's LSD test, $p<0.05)$. PM: percentage of corrected mortality; SE: standard error; ns: not significant; daa: days after application; L. cyhalothrin: lambda-cyhalothrin. Individuals expressed as the mean of PM (\%) $\pm(\mathrm{SE})$ in different assessment timings $(7 ; 14 ; 21$ and 28 daa).

\subsection{Effect of the Combination of Five Insecticides with and without an Organic Adjuvant on T. dryi}

\subsubsection{Evaluation of Treatments on T. dryi Pupae}

When T. dryi pupae were sprayed, the test showed significant differences among the treatments assayed $\left(\mathrm{F}_{10 ; 55}=13.12\right.$; and $\left.p<0.001\right)$. Dimethoate and its combination with pine oil reported the highest effects on the parasitoid pupae emergence, with a harmful response of $100 \%$ and $98 \%$ of mortality (Class 4), respectively. A moderately harmful response was displayed by acetamiprid, lambda-cyhalothrin and their respective combinations with the organic adjuvant, with a percentage between $71 \%$ and $59 \%$ (Class 3), statistically different 
compared with dimethoate treatments. The cyantraniliprole, flonicamid treatments, and their respective combinations with pine oil showed a slightly harmful incidence against T. dryi pupae, with a mortality percentage between $40 \%$ and $29 \%$ (Class 2 ), statistically different compared with the highest mortality values of but without significant differences compared with Pine oil alone. Overall, all the insecticides assayed slightly reduced their side effect on T. dryi individuals when combined with the organic adjuvant (Figure 2).

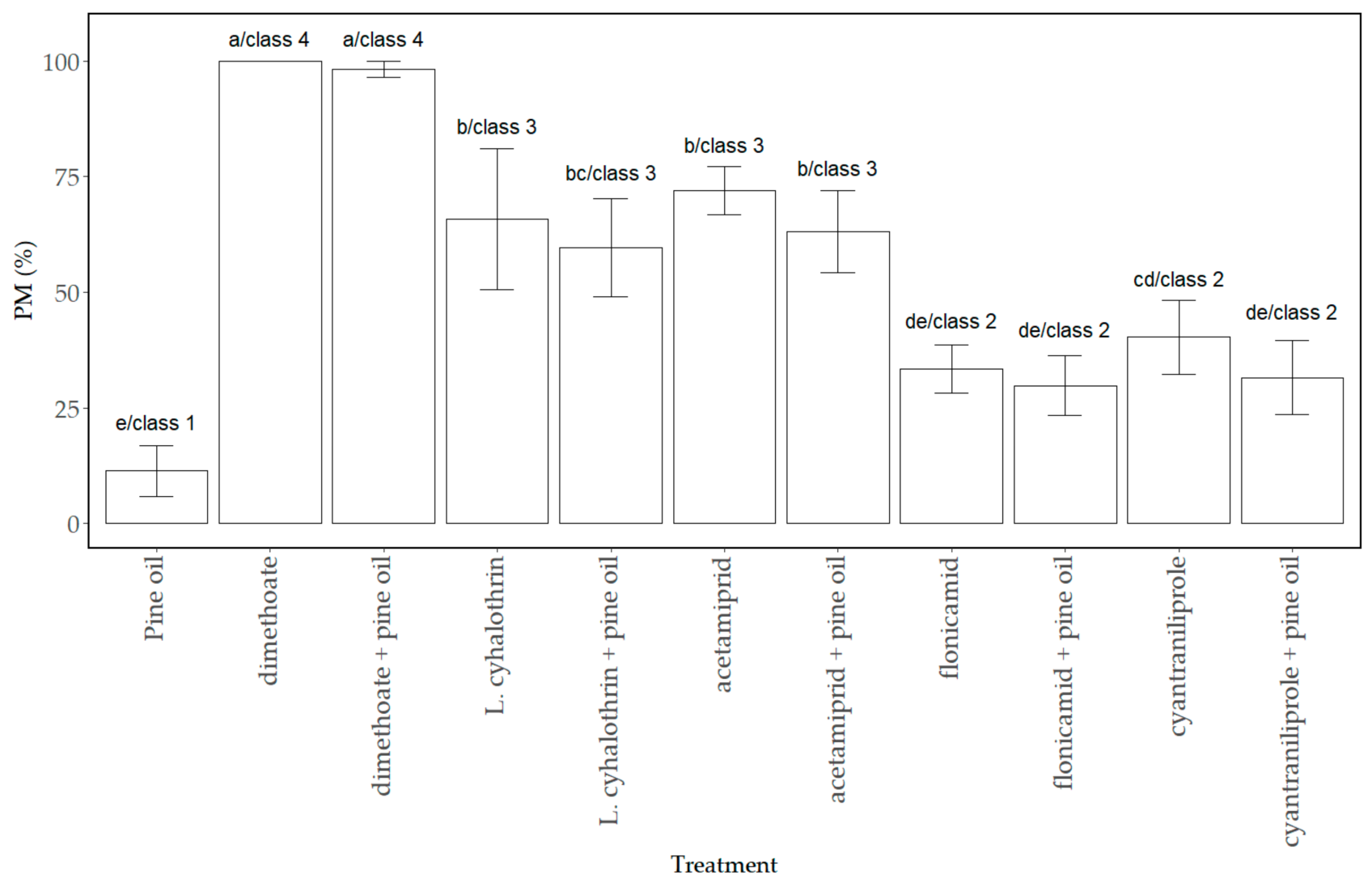

Figure 2. Effect of insecticides and their combination with a pine oil based organic adjuvant on T. dryi pupae under laboratory conditions. Colums with different letters are significantly different among the treatments tested (Fisher's LSD test, $\mathrm{p}<0.05$ ) and with different class numbers are IOBC/WPRS class based on parasitoid mortality: Class $1=\mathrm{PM}<25 \%$ (harmless): Class $2=25 \leq \mathrm{PM} \leq 50 \%$ (slightly harmful); Class $3=51 \leq \mathrm{PM} \leq 75 \%$ (moderately harmful); and Class $4=\mathrm{PM}>75 \%$ (harmful) [57-59]. PM: percentage of corrected mortality; SE: standard error; L. cyhalothrin: lambda-cyhalothrin. Values are expressed as the mean of $\mathrm{PM}(\%) \pm \mathrm{SE}$ at 7 daa.

\subsubsection{Evaluation of Treatments on T. dryi Adults}

Significant differences in T. dryi adult mortality among the treatments assayed were found $\left(\mathrm{F}_{10 ; 191}=36.95\right.$; and $\left.p<0.001\right)$ when exposed to fresh treatment residues ( 3 haa). Thus, treatment of dimethoate and its combination with pine oil reported the highest harmful response on $T$. dryi adults (Class 4 ) with statistical differences compared with the remaining treatments. Acetamiprid, acetamiprid + pine oil and lambda-cyhalothrin + pine oil displayed a slightly harmful incidence (Class 2), with significant differences compared with the highest and the lowest PM recorded. Additionally, the remaining treatments showed harmless incidence (Class 1), with the lowest mortality being recorded by cyantraniliprole + pine oil. At 7daa, significant differences of $T$. dryi adults PM were found among the treatments assayed $\left(\mathrm{F}_{10 ; 118}=3\right.$; and $\left.p=0.002\right)$. The highest mortality incidence on T. dryi adults was found with the dimethoate treatment, followed by lambdacyhalothrin, dimethoate + pine oil, lambda-cyhalothrin + pine oil (Class 2) and acetamiprid (Class 1), without statistical differences. The remaining treatments displayed lower significant incidence (Class 1), in which pine oil was the lowest harmful value. At 14 daa, 
treatment residues did not display statistical differences on $T$. dryi mortality among the treatments assayed $\left(\mathrm{F}_{10 ; 114}=1.86\right.$; and $\left.p=0.058\right)$. Hence, the highest and the lowest toxicity was achieved with acetamiprid + pine oil (Class 2) and cyantraniliprole + pine oil (Class 1), respectively, and even the latter reported a lower PM than Pine oil alone. Lastly, at 21 daa, statistical differences were found for PM T. dryi adults $\left(\mathrm{F}_{10 ; 119}=2.65\right.$; and $\left.p=0.006\right)$. The highest significant mortality rate of T. dryi was recorded by lambda-cyhalothrin (Class 2), followed by cyantraniliprole, lambda-cyhalothrin + pine oil, acetamiprid, dimethoate, and flonicamid + pine oil without significant differences. On the other hand, flonicamid, acetamiprid + pine oil, dimethoate + pine oil, and cyantraniliprole + pine oil showed harmless PM (Class 1) without significant differences compared with the pine oil treatment alone (Table 5).

Table 5. Effect of insecticides and their combination with organic pine oil-based adjuvant on T. dryi adults under laboratory conditions.

\begin{tabular}{|c|c|c|c|c|}
\hline \multirow{2}{*}{ Treatment } & \multicolumn{4}{|c|}{ PM (\%) \pm SE I Class } \\
\hline & 3 haa & 7 daa & 14 daa & 21 daa \\
\hline Pine oil & $9.06 \pm 3.61 \mathrm{~d} \mid 1$ & $5.66 \pm 1.93 \mathrm{~d} \mid 1$ & $8.05 \pm 2.56 \mathrm{~ns} \mid 1$ & $7.21 \pm 2.69 \mathrm{c} \mid 1$ \\
\hline dimethoate & $94.57 \pm 4.38 \mathrm{a} \mid 4$ & $36.54 \pm 9.55$ a $\mid 2$ & $10.82 \pm 3.80 \mathrm{~ns} \mid 1$ & $19.37 \pm 5.37 \mathrm{abc} \mid 1$ \\
\hline dimethoate + pine oil & $91.30 \pm 4.35$ a $\mid 4$ & $33.18 \pm 5.39 \mathrm{ab} \mid 2$ & $13.11 \pm 5.86 \mathrm{~ns} \mid 1$ & $15.14 \pm 4.95 \mathrm{bc|} 1$ \\
\hline L. cyhalothrin & $13.77 \pm 4.00 \mathrm{~cd} \mathrm{I} 1$ & $35.22 \pm 7.64 \mathrm{ab} \mid 2$ & $20.90 \pm 5.81 \mathrm{~ns} \mid 1$ & $33.11 \pm 5.73$ a $\mid 2$ \\
\hline L. cyhalothrin + pine oil & $25.00 \pm 8.86 \mathrm{bc|} 2$ & $22.17 \pm 6.15 \mathrm{abc} \mid 1$ & $12.13 \pm 4.60 \mathrm{~ns} \mid 1$ & $29.50 \pm 6.12 \mathrm{ab} \mid 2$ \\
\hline acetamiprid & $31.88 \pm 8.48$ b | 2 & $21.54 \pm 6.74$ abcd I 1 & $19.54 \pm 3.46 \mathrm{~ns} \mid 1$ & $26.80 \pm 6.75 \mathrm{ab} \mid 2$ \\
\hline acetamiprid + pine oil & $30.43 \pm 7.18$ b | 2 & $19.21 \pm 5.90$ bcd I 1 & $31.56 \pm 10.35 \mathrm{~ns} \mid 2$ & $10.36 \pm 5.35$ cl 1 \\
\hline flonicamid & $6.16 \pm 3.23 \mathrm{~d} \mid 1$ & $10.38 \pm 4.84 \mathrm{~cd} \mid 1$ & $11.48 \pm 5.24 \mathrm{~ns} \mid 1$ & $11.04 \pm 3.89$ c | 1 \\
\hline flonicamid + pine oil & $11.59 \pm 3.87 \mathrm{~cd} \mid 1$ & $15.72 \pm 4.30 \mathrm{~cd} \mid 1$ & $9.29 \pm 3.30 \mathrm{~ns} \mid 1$ & $17.79 \pm 4.17 \mathrm{abc} \mid 1$ \\
\hline cyantraniliprole & $9.78 \pm 4.18 \mathrm{~d} \mid 1$ & $13.21 \pm 4.39 \mathrm{~cd} \mid 1$ & $18.58 \pm 5.64 \mathrm{~ns} \mid 1$ & $31.08 \pm 8.28 \mathrm{ab} \mid 2$ \\
\hline cyantraniliprole + pine oil & $4.71 \pm 9.96 \mathrm{~d} \mid 1$ & $15.44 \pm 6.14 \mathrm{~cd} \mid 1$ & $5.96 \pm 3.99 \mathrm{~ns} \mid 1$ & $16.22 \pm 5.61 \mathrm{bc|} 1$ \\
\hline
\end{tabular}

Values with different letters are significantly different among the treatments tested per assessment period (Fisher's LSD test, $p<0.05$ ). PM: percentage of corrected mortality; SE: standard error; ns: not significant; haa: hours after application; daa: days after application; L. cyhalothrin: lambda-cyhalothrin. Values are expressed as the mean of PM (\%) \pm SE at $3 \mathrm{~h}$ after application (haa); 7 ; 14 ; and 21 days after application (daa). IOBC/WPRS class based on parasitoid mortality per assessment period: Class $1=\mathrm{PM}<25 \%$ (harmless): Class $2=25 \leq \mathrm{PM} \leq 50 \%$ (slightly harmful); Class $3=51 \leq \mathrm{PM} \leq 75 \%$ (moderately harmful); and Class $4=\mathrm{PM}>75 \%$ (harmful) $[57-59]$.

\section{Discussion}

Our study demonstrates the efficacy of different insecticide treatments and their combination with an organic adjuvant on T. erytreae and its parasitoid T. dryi via mortality incidence. A series of laboratory, semi-field and field trials showed that the inclusion of pine oil increased the efficacy of the insecticide tested on T. erytreae and reduced their negative effect on T. dryi. Insecticides are one of the most effective tools in reducing the spread of the psyllid vectors, such as Diaphorina citri (AsCP) and Trioza erytreae (AfCP) [33]. However, this method is not likely to eradicate psyllids population, but it will maintain the pest level as low as possible [23] through continuous multiple sprays on a yearly basis [4]. Chemical control is well-established preventive method against the spread and severity in HLB- free regions [33].

In South Africa, chemical control of AfCP has been carried out using insecticide foliar applications of chlorpyrifos, dimethoate, endosulfan, isofenphos, monocrotophos, oxydemeton methyl, and triazophos [17,60]. However, all of these chemical substances have been banned from agricultural use in the European Union since the 2000s, except for chlorpyrifos and dimethoate, which have recently been included in the list of banned substances [27]. In our study, we use dimethoate, lambda-cyhalothrin, acetamiprid, flonicamid, and cyantraniliprole; these chemical compounds are permitted for use in agriculture in the European Union, however dimethoate was banned after completion of our experimental study.

Results showed that the highest effectiveness of these compounds was 28 days after treatment under semi-field and field conditions, except in the case of flonicamid, which 
reported the highest mortality 21 days after application under field conditions (33.41\%). The effectiveness of sprayed insecticides ranged between $53-92 \%$ and $29-90 \%$ under semifield and field conditions at 28 daa, respectively. Our dimethoate rate was slightly lower than a rate previously reported [33] for AsCP adults and nymphs (above 90\%) for a similar assessment period. Furthermore, Qureshi et al. [33] reported an effectiveness percentage higher than $90 \%$ for lambda-cyhalothrin and no suppression with acetamiprid; these figures are not in line with our results, which reveal a mortality effect lower than $60 \%$ for lambda-cyhalothrin and $80 \%$ for acetamiprid. These differences could be accounted for by the different species of psyllid vector being evaluated. In addition, cyantraniliprole and flonicamid were our highest and lowest efficacy insecticide, respectively, which is in keeping with the effectiveness for AsCP [33]. All of these active ingredients increased their effectiveness on T. erytreae under semi-field and field conditions when combined with a pine oil adjuvant, except for acetamiprid. Similarly, Srinivasan et al. [61] demonstrated that the combination of two organic adjuvants (Silwet L-77 and Kinetic) increased the effectiveness of imidacloprid and abamectin against AsCP. Hence, the incorporation of an organic adjuvant compound improved the integrated pest management strategy implemented.

Previous studies have tested the incidence of different chemical substances on T. radiata, a natural parasitoid of the psyllid vector $D$. citri $[50,58]$. Similarly, we have assayed the same five insecticides and their combination with the organic adjuvant, as described above, on the T. erytreae parasitoid T. dryi. Beloti et al. [58] reported the lowest emergence rate for T. radiata pupae with chlorpyrifos $(18.6 \%)$ and dimethoate $(40.9 \%)$. According to our results, for $T$. dryi pupae individuals dimethoate was the most harmful compound; a moderately harmful response was obtained by lambda cyhalothrin and acetamiprid, and a slightly harmful incidence was recorded flonicamid and cyantraniliprole. Beloti et al. [58] reported the highest toxicity in $T$. radiata adults using organophosphates insecticides, such as dimethoate, which was similar to our results, in which the highest harmful response of T. dryi adults with dimethoate was reached after exposure to fresh residues $(3 \mathrm{~h}$ after application). Otherwise, we reported the highest $T$. dryi toxicity after 7-day exposure residues of lambda-cyhalothrin (35\%) and fresh residues of acetamiprid (31\%), respectively. This response is in line with the results by Beloti et al. [58], which reported mortality rates higher than $48 \%$ and $65 \%$ for lambda-cyhalothrin and acetamiprid, respectively. Additionally, our results reported a harmless response with the treatment of cyantraniliprole after $3 \mathrm{~h}$ and 7 day of the application. Conversely, the incidence of cyantraniliprole + lambda-cyhalothrin was above $48 \%$ for T. radiata adults [58]; this rate could be accounted by the high effect of lambda-cyhalothrin.

Overall, our results indicate that cyantraniliprole was the most effective treatment against T. erytreae under semi-field and field conditions. Furthermore, this insecticide did not have a negative effect on T. dryi activity, in line with the results by Tiwari and Stelinski [62] for T. radiata. This beneficial response could be due to low toxicity to nontarget and broad spectrum organisms only for sucking and chewing insects with a low chemical risk [63]. Mortality effect was even increased on T. erytreae and reduced on T. dryi when this specific chemical substance was combined with the pine oil adjuvant. Thus, cyantraniliprole alone and/or combined with pine oil proved to be the best option to be included in an integrated control strategy against T. erytreae and HLB disease. Nevertheless, in order to avoid emerging resistance, alternating with other chemical actives are recommended. In this sense, other less effective insecticides than cyantraniliprole could be deemed as potential candidates for a rotational program of chemical control of AfCP, such as lambda-cyhalothrin with pine oil adjuvant or acetamiprid, which were largely lower harmful to T. dryi than dimethoate treatments, but also effective against T. erytreae. This is not the case of flonicamid, which was the least toxic compound on the effect to T. dryi, but this substance did not report an effective control against T. erytreae. Further research will involve the evaluation of these less effective insecticides and other allowed chemical actives in Spain. 


\section{Conclusions}

Our research has reported new interesting data on several insecticides and their combinations with a pine oil organic adjuvant for use in the chemical control of Trioza erytreae in European citrus orchards, given their effectiveness against the pest and its low toxicity against its parasitoid $T$. dryi. This provides new insights on integrated pest management strategy for citrus growers, preventing the appearance of pest-chemical resistance and the emergence of HLB in free crop areas. In addition, the benefits of the use of an organic adjuvant have been confirmed in the development of more sustainable control strategies by increasing the effectiveness of the insecticide and reducing the side effects against $T$. dryi.

Author Contributions: Conceptualization, E.H.-S. and F.J.A.-A.; methodology, E.H.-S.; software, M.A.D. and J.M.A.-L.; validation, E.H.-S., A.H. and F.J.A.-A.; formal analysis, J.M.A.-L. and A.H.; investigation, M.A.D., E.H.-S. and F.S.; resources, E.H.-S., F.S. and F.J.A.-A.; data curation, M.A.D. and J.M.A.-L.; writing—original draft preparation, M.A.D. and J.M.A.-L.; writing—review and editing, E.H.-S., F.S., J.M.A.-L., A.H. and F.J.A.-A.; visualization, J.M.A.-L.; supervision, E.H.-S., F.S. and F.J.A.-A.; project administration, E.H.-S. and F.J.A.-A.; funding acquisition, E.H.-S. and F.J.A.-A. All authors have read and agreed to the published version of the manuscript.

Funding: This research was funded by the research project Network of Experimentation and Transfer in Andalusian Citrus (PR.TRA.TRA2019.001.001), which was co-financed (80\%) by the European Regional Development Fund within the FEDER Operational Program of Andalusia 2014-2020.

Institutional Review Board Statement: Not applicable.

Informed Consent Statement: Not applicable.

Data Availability Statement: Not applicable.

Acknowledgments: The authors thank Bruno Dorta for his field assistance. The authors are grateful to the commercial plot for allowing us to conduct the trial.

Conflicts of Interest: The authors declare no conflict of interest.

\section{References}

1. FAOSTAT. Food and Agriculture Organization (FAO) of the United Nations. 2021. Available online: http://www.fao.org/faostat/ es/\#home (accessed on 29 June 2021).

2. Bové, J.M. Huanglongbing: A destructive, newly-emerging, century-old disease of citrus. J. Plant Pathol. 2006, 88, 7-37.

3. Bové, J.M.; Ayres, A.J. Etiology of three recent diseases of citrus in São Paulo State: Sudden death, variegated chlorosis and huanglongbing. IUBMB Life 2007, 59, 346-354. [CrossRef]

4. Gottwald, T.R. Current epidemiological understanding of citrus Huanglongbing. Annu. Rev. Phytopathol. 2010, 48, 119-139. [CrossRef]

5. Ichinose, K.; Hoa, N.V.; Bang, D.V.; Tuan, D.H.; Dien, L.Q. Limited efficacy of guava interplanting on citrus greening disease: Effectiveness of protection against disease invasion breaks down after one year. Crop Prot. 2012, 34, 119-126. [CrossRef]

6. Jagoueix, S.; Bove, J.M.; Garnier, M. The phloem-limited bacterium of greening disease of citrus is a member of the $\alpha$ subdivision of the Proteobacteria. Int. J. Syst. Bacteriol. 1994, 44, 379-386. [CrossRef] [PubMed]

7. Hernández-Fuentes, L.M.; Urias-López, M.A.; López-Arroyo, J.I.; Gómez-Jaimes, R.; Bautista-Martínez, N. Control químico de Diaphorina citri Kuwayama (Hemíptera: Psyllidae) en lima persa Citrus latifolia Tanaka. Rev. Mex. Cien. Agríc. 2012, 3, 427-439. [CrossRef]

8. Yang, C.; Powell, C.A.; Duan, Y.; Shatters, R.G.; Lin, Y.; Zhang, M. Mitigating citrus huanglongbing via effective application of antimicrobial compounds and thermotherapy. Crop Prot. 2016, 84, 150-158. [CrossRef]

9. CABI. 2021. Available online: https:/ /www.cabi.org/isc/datasheet/16567 (accessed on 15 March 2020).

10. EPPO. European and Mediterranean Plant Protection Organization. 2021. Available online: https://gd.eppo.int/ (accessed on 15 March 2021).

11. Bové, J.M. Huanglongbing or yellow shoot, a disease of Gondwanan origin: Will it destroy citrus worldwide? Phytoparasitica 2014, 42, 579-583. [CrossRef]

12. Bové, J.M.; Durán-Vila, N. ¿El huanglongbing va a destruir la citricultura mediterránea? Phytoma España 2016, 277, 18-28.

13. López, M.M.; Marco-Noales, E.; Bertolini, E. Aumenta el riesgo de huanglongbing, causado por Candidatus Liberibacter spp., que supone la mayor amenaza actual para la citricultura española. Phytoma España Rev. Prof. Sanid. Veg. 2015, $270,32-34$.

14. Siverio, F.; Marco-Noales, E.; Bertolini, E.; Teresani, G.R.; Peñalver, J.; Mansilla, P.; Aguín, O.; Pérez-Otero, R.; Abelleira, A.; Guerra-García, J.A.; et al. Survey of huanglongbing associated with "Candidatus Liberibacter" species in Spain: Analyses of citrus plants and Trioza erytreae. Phytopathol. Mediterr. 2017, 56, 98-110. [CrossRef] 
15. Gottwald, T.R.; Bassanezi, R.B.; Paulo, S. Citrus Huanglongbing: The pathogen and its impact. Plant Health Prog. $2007,8,36$. [CrossRef]

16. Ajene, I.J.; Khamis, F.; Mohammed, S.; Rasowo, B.; Ombura, F.L.; Pietersen, G.; van Asch, B.; Ekesi, S. First report of field population of Trioza erytreae carrying the Huanglongbing-associated pathogen, Candidatus Liberibacter asiaticus, in Ethiopia. Plant Dis. 2019, 103, 1766. [CrossRef]

17. Van den Berg, M.A. The citrus pyslla, Trioza erytreae (Del Guercio) (Hemiptera: Triozidae): A review. Agric. Ecosyst. Environ. 1990, 30, 171-194. [CrossRef]

18. EPPO Global Database. 2021. Available online: https:/ /gd.eppo.int/ (accessed on 15 March 2021).

19. González Hernández, A. Trioza erytreae (Del Guercio 1918): Nueva plaga de los citricos en Canarias. Phytoma España Rev. Prof. Sanid. Veg. 2003, 153, 112-118.

20. Pérez-Otero, R.; Mansilla, J.P.; Del Estal, P. Detección de la psila africana de los cítricos, Trioza erytreae (Del Guercio, 1918) (Hemiptera: Psylloidea: Triozidae), en la Península Ibérica. Arq. Entomolóxicos 2015, 13, 119-122.

21. Arenas-Arenas, F.J.; Duran-Vila, N.; Quinto, J.; Hervalejo, Á. Is the presence of Trioza erytreae, vector of huanglongbing disease, endangering the Mediterranean citrus industry? Survey of its population density and geographical spread over the last years. $J$. Plant Pathol. 2018, 100, 567-574. [CrossRef]

22. Arenas-Arenas, F.J.; Duran-Vila, N.; Quinto, J.; Hervalejo, Á. Geographic spread and inter-annual evolution of populations of Trioza erytreae in the Iberian Peninsula. J. Plant Pathol. 2019, 101, 1151-1157. [CrossRef]

23. Cocuzza, G.E.M.; Urbaneja, A.; Hernández-Suárez, E.; Siverio, F.; Di Silvestro, S.; Tena, A.; Rapisarda, C. A review on Trioza erytreae (African citrus psyllid), now in mainland Europe, and its potential risk as vector of huanglongbing (HLB) in citrus. J. Pest Sci. 2016, 90, 1-17. [CrossRef]

24. Urbaneja-Bernat, P.; Pérez-Rodríguez, J.; Krüger, K.; Catalán, J.; Rizza, R.; Hernández-Suárez, E.; Urbaneja, A.; Tena, A. Host range testing of Tamarixia dryi (Hymenoptera: Eulophidae) sourced from South Africa for classical biological control of Trioza erytreae (Hemiptera: Psyllidae) in Europe. Biol. Control 2019, 135, 110-116. [CrossRef]

25. Monzo, C.; Stansly, P.A. Economic injury levels for Asian citrus psyllid control in process oranges from mature trees with high incidence of huanglongbing. PLOS ONE 2017, 12, e0175333. [CrossRef]

26. Rizza, R.; Hernández-Suárez, E.; Perera, S.; Quinto, J.; Hervalejo, A.; Siverio, F.; Arenas-Arenas, F.J. Evaluación de la eficacia de estrategias de manejo químico para el control de Trioza erytreae (Hemiptera: Triozidae) en España. Levante Agrícola Rev. Int. cítricos 2019, 446, 65-70.

27. EU law_EUR-Lex. Access to European Union Law. 2021. Available online: https:/ / eur-lex.europa.eu/homepage.html (accessed on 25 June 2021).

28. Tiwari, S.; Mann, R.S.; Rogers, M.E.; Stelinski, L.L. Insecticide resistance in field populations of Asian citrus psyllid in Florida. Pest Manag. Sci. 2011, 67, 1258-1268. [CrossRef] [PubMed]

29. Dávila Medina, M.D.; Cerna Chávez, E.; Aguirre Uribe, L.A.; García Martínez, O.; Ochoa Fuentes, Y.M.; Gallegos Morales, G.; Landeros Flores, J. Susceptibilidad y mecanismos de resistencia a insecticidas en Bactericera cockerelli (Sulc.) en Coahuila, México. Rev. Mex. Cien. Agríc. 2012, 3, 1145-1155.

30. Tiwari, S.; Clayson, P.J.; Kuhns, E.H.; Stelinski, L.L. Effects of buprofezin and diflubenzuron on various developmental stages of Asian citrus psyllid, Diaphorina citri. Pest Manag. Sci. 2012, 68, 1405-1412. [CrossRef] [PubMed]

31. Tiwari, S.; Killiny, N.; Stelinski, L.L. Dynamic insecticide susceptibility changes in Florida populations of Diaphorina citri (Hemiptera: Psyllidae). J. Econ. Entomol. 2013, 106, 393-399. [CrossRef] [PubMed]

32. Grafton-Cardwell, E.E.; Stelinski, L.L.; Stansly, P.A. Biology and management of Asian citrus psyllid, vector of the huanglongbing pathogens. Annu. Rev. Entomol. 2013, 58, 413-432. [CrossRef]

33. Qureshi, J.A.; Kostyk, B.C.; Stansly, P.A. Insecticidal suppression of asian citrus psyllid Diaphorina citri (Hemiptera: Liviidae) vector of huanglongbing pathogens. PLoS ONE 2014, 9, 1-22. [CrossRef]

34. Qureshi, J.A.; Stansly, P.A. Integrated approaches for managing the Asian citrus psyllid Diaphorina citri (Homoptera: Psyllidae) in Florida. In Proceedings of the Florida State Horticultural Society, Lake Alfred, FL, USA, 2007; Volume 120, pp. 110-115.

35. Vega-Gutierrez, M.T.; Rodriguez-Maciel, C.J.; Diaz-Gomez, O.; Bujanos-Muniz, R.; Mota-Sanchez, D.; Martinez-Carrillo, L.J.; Lagunes-Tejeda, A.; Garzon-Tiznado, J.A. Susceptibility to insecticides in two Mexican populations of tomato-potato psyllid, Bactericera cockerelli (Sulc.) (Hemiptera: Triozidae). Agrociencia 2008, 42, 463-471.

36. Carvalho, F.P. Pesticides, environment, and food safety. Food Energy Secur. 2017, 6, 48-60. [CrossRef]

37. Bakırcı, G.T.; Yaman Acay, D.B.; Bakırcı, F.; Ötleş, S. Pesticide residues in fruits and vegetables from the Aegean region, Turkey. Food Chem. 2014, 160, 379-392. [CrossRef]

38. Hoganson, D.A.; Stahly, D.P. Regulation of dihydrodipicolinate synthase during growth and sporulation of Bacillus cereus. J. Bacteriol. 1975, 124, 1344-1350. [CrossRef]

39. Catling, H.D. The bionomics of the South African citrus psylla, Trioza erytreae (Del Guercio) (Homoptera: Psyllidae). 1. The influence of the flushing rhythm of citrus and factors which regulate flushing. J. Entomol. Soc. South. Afr. 1969, 32, $273-290$.

40. Mc Daniel, J.R.; Moran, V.C. The parasitoid complex of the citrus psylla Trioza erytreae (Del Guercio) [Homoptera: Psyllidae] Entomophaga 1972, 17, 297-317. [CrossRef]

41. Van den Berg, M.A.; Greenland, J. Tamarixia dryi, parasitoid of the citrus psylla, Trioza erytreae: A review. Afr. Plant Prot. 2000, 6, $25-28$. 
42. Tamesse, J.L.; Messi, J. Incidence de Trioza erytreae (del Guercio) (Homoptera: Triozidae), psylle vecteur du greening sur la sensibilité des plantules d'agrumes dans une pépinière au Cameroun. Int. J. Trop. Insect Sci. 2002, 22, 97-103. [CrossRef]

43. Pérez-Rodríguez, J.; Krüger, K.; Pérez-Hedo, M.; Ruíz-Rivero, O.; Urbaneja, A.; Tena, A. Classical biological control of the African citrus psyllid Trioza erytreae, a major threat to the European citrus industry. Sci. Rep. 2019, 9, 9440. [CrossRef]

44. Etienne, J.; Aubert, B. Biological control of psyllid vectors of greening disease on Reunion Island. In Proceedings of the 8th International Organization of Citrus Virologists, International Organization of Citrus Virologists; University of California: Riverside, CA, USA, 1980; Volume 8, pp. 118-121.

45. Aubert, B.; Quilici, S. Monitoring adult psyllas on yellow traps in Reunion Island. In Proceedings of the International Organization of Citrus Virologists Conference Proceedings (1957-2010); University of California: Riverside, CA, USA, 1988; Volume 10, pp. 249-254.

46. Fernandes, A.; Aguiar, A.M.F. Situação actual das pragas dos citrinos Toxoptera citricida (Kirkaldy) e Trioza erytreae (Del Guercio) na Região Autónoma da Madeira. In Proceedings of the Actas do Congreso Nacional de Citricultura, Faro, Portugal; 2002; Volume 4, pp. 621-627. Available online: https://www.researchgate.net/publication/233819620_Situacao_actual_ das_pragas_dos_citrinos_Toxoptera_citricida_Kirkaldy_e_Trioza_erytreae_Del_Guercio_na_Regiao_Autonoma_da_Madeira (accessed on 1 September 2021).

47. Hernández-Suárez, E.; Pérez-Rodríguez, J.; Suárez-Méndez, L.; Urbaneja-Bernat, P.; Rizza, R.; Siverio, F.; Piedra-Buena, A.; Urbaneja, A.; Tena, A. Control de Trioza erytreae en las Islas Canarias por el parasitoide Tamarixia dryi. Phytoma España. Rev. Prof. Sanid. Veg. 2020, 319, 28-32.

48. Bueso, G. Primeras sueltas experimentales de Tamarixia dryi en la península. Phytoma España Rev. Prof. Sanid. Veg. 2020, 315, 16-17.

49. Yamamoto, P.T.; Alves, G.R.; Beloti, V.H. Manejo e controle do huanglongbing (HLB) dos cítricos. Investig. Agrar. 2015, 16, 69-82.

50. Hall, D.G.; Nguyen, R. Toxicity of pesticides to Tamarixia radiata, a parasitoid of the Asian citrus psyllid. BioControl 2010, 55, 601-611. [CrossRef]

51. Interactive MoA Classification I Insecticide Resistance Action Committee (IRAC). Available online: https:/ /irac-online.org/ modes-of-action/ (accessed on 10 May 2021).

52. Sparks, T.C.; Nauen, R. IRAC: Mode of action classification and insecticide resistance management. Pestic. Biochem. Physiol. 2015, 121, 122-128. [CrossRef] [PubMed]

53. Abbott, W.S. A method of computing the effectiveness of an insecticide. J. Econ. Entomol. 1925, 18, 265-267. [CrossRef]

54. Steel, R.G.D.; Torrie, J.H. Principles and Procedures of Statistics: With Special Reference to the Biological Sciences; McGraw-Hill Book Company, Inc.: New York, NY, USA, 1960.

55. R Development Core Team. R: A Language and Environment for Statistical Computing; R Foundation for Statistical Computing: Vienna, Austria, 2020; ISBN 3-900051-07-0. Available online: https:/ / www.r-project.org/ (accessed on 22 December 2020).

56. de Mendiburu, F. Statistical Procedures for Agricultural Research; Package "Agricolae", Version 1.4-4, Comprehensive R Archive Network; Institute for Statistics and Mathematics: Vienna, Austria, 2013.

57. Hassan, S.A.; Bigler, F.; Bogenschütz, H.; Boller, E.; Brun, J.; Calis, J.N.M.; Coremans-Pelseneer, J.; Duso, C.; Grove, A.; Heimbach, U.; et al. Results of the sixth joint pesticide testing programme of the IOBC/WPRS-working group "pesticides and beneficial organisms». Entomophaga 1994, 39, 107-119. [CrossRef]

58. Beloti, V.H.; Alves, G.R.; Araújo, D.F.D.; Picoli, M.M.; Moral, R.D.A.; Demétrio, C.G.B.; Yamamoto, P.T. Lethal and sublethal effects of insecticides used on citrus, on the ectoparasitoid Tamarixia radiata. PLoS ONE 2015, 10, e0132128. [CrossRef]

59. Van de Veire, M.; Sterk, G.; Van der Staaij, M.; Ramakers, P.M.J.; Tirry, L. Sequential testing scheme for the assessment of the side-effects of plant protection products on the predatory bug Orius laevigatus. BioControl 2002, 47, 101-113. [CrossRef]

60. Aubert, B. Trioza erytreae Del Guercio and Diaphorina citri Kuwayama (Homoptera: Psyllidae), the two vectors of citrus greening disease: Biological aspects and possible control strategies. Fruits 1987, 42, 149-162.

61. Srinivasan, R.; Hoy, M.A.; Singh, R.; Rogers, M.E. Laboratory and field evaluations of Silwet L-77 and kinetic alone and in combination with imidacloprid and abamectin for the management of the Asian citrus psyllid, Diaphorina citri (Hemiptera: Psyllidae). Florida Entomol. 2008, 91, 87-100. [CrossRef]

62. Tiwari, S.; Stelinski, L.L. Effects of cyantraniliprole, a novel anthranilic diamide insecticide, against Asian citrus psyllid under laboratory and field conditions. Pest Manag. Sci. 2013, 69, 1066-1072. [CrossRef] [PubMed]

63. Sattelle, D.B.; Cordova, D.; Cheek, T.R. Insect ryanodine receptors: Molecular targets for novel pest control chemicals. Invertebr. Neurosci. 2008, 8, 107-119. [CrossRef] [PubMed] 